Meta

Journal des traducteurs

Translators' Journal

\title{
Repetition in Literary Arabic: Foregrounding, Backgrounding, and Translation Strategies
}

\section{Hisham A. Jawad}

Volume 54, numéro 4, décembre 2009

URI : https://id.erudit.org/iderudit/038902ar

DOI : https://doi.org/10.7202/038902ar

Aller au sommaire du numéro

\section{Éditeur(s)}

Les Presses de l'Université de Montréal

ISSN

0026-0452 (imprimé)

1492-1421 (numérique)

Découvrir la revue

Citer cet article

Jawad, H. A. (2009). Repetition in Literary Arabic: Foregrounding, Backgrounding, and Translation Strategies. Meta, 54(4), 753-769. https://doi.org/10.7202/038902ar

\section{Résumé de l'article}

Le présent article examine la répétition lexicale dans des textes littéraires arabes et dans leurs traductions en anglais. Le matériel textuel utilisé est constitué par l'autobiographie, en trois parties, de Tāhā Hussein (al-Ayyām) et de sa traduction intitulée The Days. Une mise en correspondance du texte cible et du texte source a été réalisée de manière à révéler la manière dont les répétitions lexicales sont rendues dans les traductions et à déterminer les stratégies et les normes mises en jeu dans certains choix traductionnels. Trois types de répétition sont étudiés : les répétitions d'unités lexicales, de doublons lexicaux et de phrases. Les répétitions d'unités lexicales ont deux fonctions principales, l'une textuelle, l'autre rhétorique. La première concerne la structure et la cohésion du texte, potentiellement organisé par les répétitions, tandis que la seconde suscite une image mentale de fond ou évoque des émotions au moyen d'un langage émotif. La traduction de la deuxième partie de l'autobiographie est caractérisée essentiellement par l'absence de répétitions lexicales, contrairement à celle de la première et de la troisième partie. Par conséquent, le texte cible ne représente pas fidèlement l'auteur, puisqu'il semble mettre en évidence trois étapes de développement stylistique et textuel distinctes. En ce qui concerne les stratégies de traduction, les résultats indiquent que les traducteurs introduisent, par rapport au texte source, des variations faisant appel à différents schémas référentiels. La répétition rhétorique passe à l'arrière-plan chez au moins un traducteur qui la remplace par une variation généralisée. L'ambivalence des stratégies mènerait à une représentation erronée du texte original (et peut-être aussi de l'auteur), qui semble alors hétérogène. Les différentes stratégies utilisées révèlent l'attitude de chacun des traducteurs à l'égard des normes liées au texte source et leur adhésion aux normes linguistiques et culturelles dominantes dans le contexte du texte cible. De façon générale, on observe que les normes liées au texte source ou au texte cible influencent le traducteur de façon variable. Il semble raisonnable d'affirmer que la tendance générale des normes traductionnelles va, pour reprendre les termes du modèle des normes de Toury, plutôt vers le pôle de l'acceptabilité que vers celui de l'adéquation. Autrement dit, la stratégie adoptée est orientée vers le texte cible.
Ce document est protégé par la loi sur le droit d'auteur. L’utilisation des services d'Érudit (y compris la reproduction) est assujettie à sa politique d'utilisation que vous pouvez consulter en ligne.

https://apropos.erudit.org/fr/usagers/politique-dutilisation/ 


\title{
Repetition in Literary Arabic: Foregrounding, Backgrounding, and Translation Strategies
}

\author{
HISHAM A. JAWAD \\ Sultan Qaboos University, Muscat, Oman \\ hajawad@hotmail.com
}

\begin{abstract}
RÉSUMÉ
Le présent article examine la répétition lexicale dans des textes littéraires arabes et dans leurs traductions en anglais. Le matériel textuel utilisé est constitué par l'autobiographie, en trois parties, de Tāhā Hussein (al-Aypām) et de sa traduction intitulée The Days. Une mise en correspondance du texte cible et du texte source a été réalisée de manière à révéler la manière dont les répétitions lexicales sont rendues dans les traductions et à déterminer les stratégies et les normes mises en jeu dans certains choix traductionnels. Trois types de répétition sont étudiés: les répétitions d'unités lexicales, de doublons lexicaux et de phrases. Les répétitions d'unités lexicales ont deux fonctions principales, l'une textuelle, l'autre rhétorique. La première concerne la structure et la cohésion du texte, potentiellement organisé par les répétitions, tandis que la seconde suscite une image mentale de fond ou évoque des émotions au moyen d'un langage émotif. La traduction de la deuxième partie de l'autobiographie est caractérisée essentiellement par l'absence de répétitions lexicales, contrairement à celle de la première et de la troisième partie. Par conséquent, le texte cible ne représente pas fidèlement l'auteur, puisqu'il semble mettre en évidence trois étapes de développement stylistique et textuel distinctes. En ce qui concerne les stratégies de traduction, les résultats indiquent que les traducteurs introduisent, par rapport au texte source, des variations faisant appel à différents schémas référentiels. La répétition rhétorique passe à l'arrière-plan chez au moins un traducteur qui la remplace par une variation généralisée. L'ambivalence des stratégies mènerait à une représentation erronée du texte original (et peut-être aussi de l'auteur), qui semble alors hétérogène. Les différentes stratégies utilisées révèlent l'attitude de chacun des traducteurs à l'égard des normes liées au texte source et leur adhésion aux normes linguistiques et culturelles dominantes dans le contexte du texte cible. De façon générale, on observe que les normes liées au texte source ou au texte cible influencent le traducteur de façon variable. Il semble raisonnable d'affirmer que la tendance générale des normes traductionnelles va, pour reprendre les termes du modèle des normes de Toury, plutôt vers le pôle de l'acceptabilité que vers celui de l'adéquation. Autrement dit, la stratégie adoptée est orientée vers le texte cible.
\end{abstract}

\footnotetext{
ABSTRACT

The paper investigates lexical repetition in Arabic original literary texts and English translations. The empirical base material consists of a three-part autobiography (al-Aypām, by Tāhā Hussein) and its translation (The Days). The method involves a mapping of the target text (TT) onto the source text (ST) so as to see how instances of lexical repetition are rendered into the translations and what are the strategies and norms involved in determining certain translation choices. Three types of lexical repetition are studied: lexical-item repetition, lexical-doublet repetition and phrase repetition. Lexical repetition serves two major functions, namely textual and rhetorical. The textual function concerns the potential of repetition for organising the text and rendering it cohesive, while the rhetorical foregrounds a mental image or invokes emotions in emotive language. It is observed that the translation of the autobiography's second part is characterised mainly by the absence of lexical repetition, contrary to the translations of the first and third parts.
}

Meta LIV, 4, 2009 
Thus, the target text misrepresents the original author as passing through three stages of textual, stylistic development. As to the translation strategies, the findings suggest that the translators vary the ST by using different patterns of reference. Rhetorical repetition is backgrounded by at least one translator who replaces it with pervasive variation. It is argued that the ambivalence of their approaches leads to a misrepresentation of the original text (and perhaps the author) as rather uneven.The strategies for translating lexical repetition highlight the translators' individual attitudes towards the ST's norms and their adherence to the linguistic and cultural norms prevalent in the TL environment. On the whole, there is a variation in the degree of bias towards the norms of either SL or TL. In terms of Toury's norms model, it may be safe to claim that the general trend of translational norms seems to lean more towards the acceptability pole than the adequacy pole, i.e., a TL-oriented strategy is opted for.

\section{MOTS-CLÉS/KEYWORDS}

répétition, avant-plan, arrière-plan, stratégies de traduction, normes repetition, foregrounding, backgrounding, translation strategies, norms

\section{Introduction}

Repetition has widely been studied from the perspectives of traditional linguistics, text linguistics, and literary studies. As a result, many models and insights have been articulated in an attempt to describe and explain the manifestations and mechanisms underlying this phenomenon. Some researchers have seen repetition as a textual device functioning in a way so as to realize lexical cohesion (Halliday and Hasan 1976; Beaugrande and Dressler 1981; Hasan 1984; amongst others). Others have argued for the central role repetition plays in the overall organization of text (Hoey 1991). And, it is in poetics that repetition demonstrates still greater effect as it is employed artistically and rhetorically to foreground linguistic elements in text (Wright 1965; Leech 1969; Gutwinski 1976).

One kind of repetition is lexical repetition, or recurrence, which is used to serve two major cohesive functions: textual and rhetorical. As for the textual function, the device is utilized in connecting various parts of a text through the unmarked recurrence of certain elements at the very surface of the text. In this, lexical repetition assumes the role of organizing and rendering the text cohesive in much the same way as connectives do. Rhetorically, lexical repetition has to do with the expressive meaning that a marked repetitive pattern evokes via a foregrounded, rhetorical image. However, it must be emphasised that the two functions occasionally shade into one another to the extent that it becomes almost impossible to determine which function is at work. The fact that lexical repetition caters to the organization of text by integrating various items into a cohesive network will necessarily entail the deployment of words which refer to closely related ideas or entities into repetitive patterns. Here, the style of the author informs the process of constructing the text and, consequently, repetition is bound to acquire some authorial, stylistic make-up. In other words, the textual and rhetorical functions of repetition may be said to overlap with some other stylistic function.

This paper discusses lexical repetition in Arabic original literary texts and English translations. The analytical methodology of the study is eclectic. It draws on several different theories of the notion of norms that involve a component of comparison informing a mapping of the TT onto the ST. This approach will have the 
discovery of translation strategies as its ultimate goal. However, this work is less concerned with translation strategies as theoretical concepts than with their practical application. I shall not, therefore, attempt to look into their theoretical status or definition. Specifically, I shall focus on the production strategies which "have to do with how the translator manipulates the linguistic material in order to produce an appropriate target text" (Chesterman 1997: 92). A strategy, then, is an action taken by the translator in a problem-solving situation. Numerous catalogues of translation strategies have been put forward (Vinay and Darbelnet 1958/1995; Baker 1992; Dickins, Hervey et al. 2002), however, studies on strategies for translating Arabic discourse are hard to come by. Therefore, it may be necessary to identify the strategies translators frequently employ in the process of translating. One strategy of rendering Arabic lexical repetition into English is variation. This is partly motivated by the TL systemic prerequisites and the general, stylistic norms prevalent in the TL environment that inform such tendencies as the subscription to fluency, idiomaticity, or eloquence. In achieving lexical cohesion, English TL norms call for the use of elegant variation as an alternative to repetition when the latter serves no expressive function (Leech and Short 1981: 247). The device of variation may take a set of forms (synonymy, co-reference, etc.) depending on the kinds of shift translators trigger in the TT. This, however, does not rule out facilitating repetition in cases informed by ST norms. The decision to apply a certain TT solution to a certain ST problem is essentially dependent on how sensitive the translators are towards the ST message and the necessity to relay textual features and structures into the TT.

The notion of norms, originating in the socio-cultural studies, is so significant here as it concerns the system of values and beliefs specific to a particular culture, society, and time. It has been applied to linguistics by Bartsch (1987) and to translation by Toury (1995), among others. Toury's definition of norms, however, is biased towards descriptive translation studies as it refers to "the translation of general values or ideas shared by a community - as to what is right and wrong, adequate and inadequate - into performance instructions appropriate for and applicable to particular situations" (Toury 1995: 55). The norms are identified in a corpus of source and target texts, the scrutiny of which would help to uncover translation strategies that are repeatedly opted for in preference to other available strategies in a given language or culture. Thus, whilst adherence to source norms determines a translation's adequacy as compared to the source text, subscription to norms originating in the target culture determines its acceptability. Schäffner (1999: 13) underlines the significance of the concept of norms in linguistic approaches to translation, as both linguistic and translational norms emanate from the process of mapping the TT onto the ST.

In the following sections, there will be an investigation of the types of lexical repetition as they occur in Arabic original texts and how they are dealt with in the English translation. The empirical base material for this study consists of the threepart autobiography al-Ayyām ${ }^{1}$ by Tāhā Hussein along with the translations, The Days. The three parts have been translated by three different translators. ${ }^{2,3,4}$ The texts were selected on the basis of Tāhā Hussein's wide reputation as a writer whose immeasurable contributions to the Arabic language and literature were set in motion through a mastery of flexible, lucid Arabic prose style. In fact, his autobiography is considered as one of the acknowledged masterpieces of contemporary Arabic literature, which signified the beginning of a new era in the history of Arabic writing in general, and 
the art of fiction in particular. Thus, the text is more in the genre of fiction than pure autobiography.

Tāhā Hussein (1889-1973), blind from early childhood, managed to pursue a distinguished career in Egyptian and Arab cultural life. Unofficially known as Dean of Arabic Letters, he was mostly influential through his varied and controversial writings. Pierre Cachia, in his brief introduction to the one-volume three translations of the autobiography, refers to the generation of Arab intellectuals of which Tāhā Hussein was the "most representative and most immediately influential member":

They were not cautious philosophers or meticulous scholars, but bold spirits casting their bread upon the waters [...]. Their achievement was that they swept away conservatism part of which at least badly needed to be swept away; they accustomed an entire generation to thinking along new lines (Cachia, Preface. In: Hussein 1932/1997: 4).

He adds: "Of the qualities that enabled Tāhā Hussein to leave his mark on an entire nation, his sensitiveness and independence of spirit shine through every page of his autobiography" (Cachia, Preface. In: Hussein 1932/1997: 4). Ultimately, the selection of the text rested upon one major objective, namely to elicit typical examples of repetition from a typical discourse of repetition. Along these lines, it may be claimed that Tāhā Hussein was a master of Arabic poetic prose and repetition. This will be shown through the ways repetition is utilised in the overall building of text. First, attention will be paid to the textual function of repetition and then to the rhetorical through discussing a number of examples in conjunction with the strategies adopted in translating them. With the textual function in mind, lexical repetition will be examined in terms of three types: lexical-item repetition, lexical-doublet repetition and phrase repetition. Still, one further function to be discussed is the rhetorical.

\section{Lexical-item repetition}

This type refers to the recurrence of one word across a stretch of text. A number of examples will be analysed from the vantage point of the strategies employed by various translators.

\subsection{Translation strategies}

There have been four strategies used by the translators for rendering repetition into the English TT.

\subsubsection{Literal translation}

This strategy is meant to be as close to the ST form as possible but still grammatical.

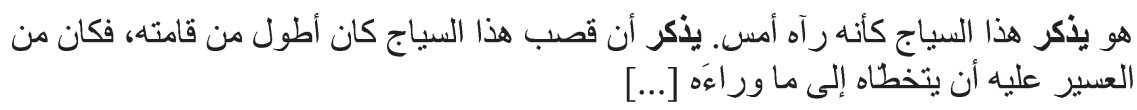

(Hussein Pt. 1: 4)

He remembers the fence as though he saw it only yesterday. He remembers that the stalks of which this fence was composed were taller than he was, and it was difficult for him to get to the other side of it [...] (Hussein 1932/1997: 9, translated by Paxton) 
This first example is extracted from the very beginning of Tāhā Hussein's autobiography. It shows a small portion of a repetitive pattern set by the verb يذكر that occurs no fewer than fourteen times in the first three pages of the ST. The lexical item runs almost like a theme through the pages setting the scene for the topic of the whole text, i.e., remembering. The function of this item repetition may be seen as twofold: stylistic and text-building. In the TT, the equivalent item remember is used twelve times, while for the other two occurrences variation is opted for, e.g., recall and recollect. That is, the chain of lexical-item repetition is disrupted in the middle by two synonyms in the TT. More than that, the lexical chain is stretched out in the TT when the translator introduces remember as a substitute for the word (literally to memorise) which occurs in the fourth page. This manipulation may be viewed from the perspective of translation norms where the choice is an outcome of a conscious translation processing of the ST. In other words, the translator has presumably been aware of the unusual recurrence of the item and its significance to the overall theme of the first chapter, which is centred on the notion of remembering. Therefore, the expansion of the chain may be informed by two factors: the excessive reiteration of the item and the theme of the first chapter.

\subsubsection{Translation by synonymy}

This strategy selects not the exact equivalent but a synonym or near-synonym for it.

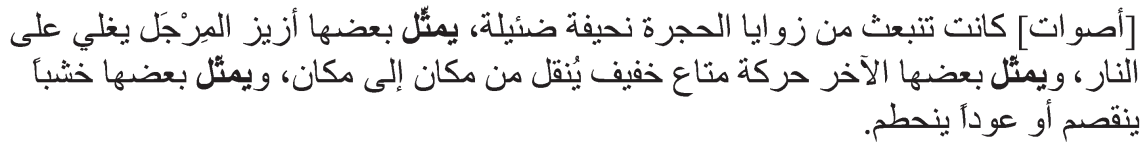

(Hussein Pt. 1: 8)

[...] sounds which proceeded softly from the corners of the room. Some of them were like the hissing of a kettle boiling on the fire, others resembled the movement of light articles being moved from place to place, and again others sounded like the breaking of wood or the cracking of stems.

(Hussein 1932/1997: 11, translated by Paxton)

In this second example, the verb يمثّل is repeated no fewer that three times as highlighted. The translator opts for the corresponding items were like, resembled and sounded like. The recurrence of each of these could qualify as a possible alternative in the TT, although the choices are somehow constrained by the collocation preferences in the context in which they occur. To take one example, the word resemble is often used with reference to visual appearances or properties. In terms of cohesive ties, the ST favours identical repetition for linking the three clauses starting with يمثّل The item creates a cohesive chain coupled by another one which is formed by the neighbouring word بعضها. In the TT, however, the strategy is to establish different cohesive ties by linking the last choice sounded like with the other preceding items in two ways: by repetition in like/like, and by synonymy in sounded like/resembled. That is, while the ST sets the repetitive pattern in a way so as to stretch out like a thread across the passage, the translation strategy cuts it in the middle (by resembled) and replaces it with two links interfaced by sounded like.

Another point has to do with the notion of textual continuity in terms of the average distance between one occurrence and another of the same item. The above 
example displays a variation between the ST and TT systems of norms in the sense that the tendency to set a cohesive linkage by short-range repetition in the ST is contrasted with a TT tendency for long-range repetition. It has been suggested that Arabic and English differ in the level of tolerance towards lexical repetition (Baker 1992: 210). Normally, Arabic tolerates a higher degree of lexical repetition than English. However, this is only partially true, given the fact that the frequency of recurrence is ultimately constrained by the parameter of textual distance, i.e., the average range of distance between one occurrence and another of the same item at the surface of the text. Thus, while Arabic allows recurrence to take place at a variety of ranges, including the short-range, English seems to prefer recurrence at a long distance but employs co-reference or pronominalization in short-range linking. This norm operates in the next example.

\subsubsection{Translation by hyponymy}

The translator replaces a ST lexical repetitive set with another set based on a hyponymic association.

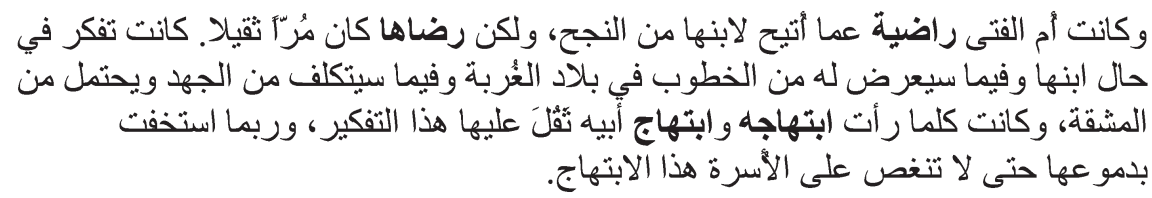

(Hussein Pt. 3: 70)

My mother [the mother of the boy], too, was pleased with her son's measure of success. But her satisfaction was clouded with heavy apprehensions, thinking of my [his] blind state and all the vicissitudes awaiting me [him] in a strange land, the exertions necessary and the hardships I [he] would undergo. These thoughts would come weighing on her at every sight of my [his] happy anticipation and my [his] father's satisfaction. Oftentimes she checked her tears in order not to mar the family joy.

(Hussein 1976/1997: 312, translated by Cragg)

In the ST passage, there are two kinds of lexical repetition: root repetition as in رضا - راضية and repetition of the lexical item ابتهاج. Whilst the lexical set with root repetition is rendered synonymous in the TT, i.e., pleased and satisfaction, the second set involving lexical-item repetition undergoes another strategy. The three occurrences of ابتهاج are replaced with anticipation, satisfaction, and joy. These items constitute a lexical set belonging to the semantic field of EMOTION, but they are assigned different values on the scale of generality. Specifically, satisfaction denotes the feeling one gets after achieving something or when a wish is fulfilled; anticipation is a feeling of excitement (which collocates with the added word happy); and joy is a feeling of great happiness, delight (Wehmeier 2000). This shows that anticipation and joy are more specific in their meaning than satisfaction and that they stand as synonyms or near-synonyms for ابتهاج الباج. Satisfaction, on the other hand, cannot qualify as a (near) synonym for ابتهاج إنهاج. In fact, it is more general in its meaning which denotes the sense of رضا. Similarly, a relationship of hyponymy exists between satisfaction as a superordinate and anticipation and joy as co-hyponyms. The ST hyponymic relationship attributes the superordinate element رضا to the mother and the hyponym ابتهاج to the rest of the family including the father and son. What the translator 
does is deconstruct this equation by shifting the semantic pattern to cover both parents on the one hand and the rest of the family on the other, i.e., assigning satisfaction to the parents, anticipation to the son and joy to other family members. Put another way, the superordinate linguistic element is allocated to superordinate family members, while hyponyms relate to lower family members. This semantic interpretation of the ST can hardly be justified given the fact that the values attributed to the feelings of each individual in the ST are conspicuous.

\subsubsection{Translation by homophony}

This strategy replaces the ST repetitive pattern with another one based on phonetic identity.

$$
\text { ] كان أقرب من أبيه إلى الدنيا ، وأبعد من أبيه عن الدين . }
$$

(Hussein Pt. 1: 89)

$[\ldots]$ he was nearer to worldly things than his father and farther removed from the things of religion.

(Hussein 1932/1997: 53, translated by Paxton)

In this fourth example, the element أبيه is repeated twice. The translator has attempted to reproduce the phonic aspect of the ST pattern by employing the device of homophony. Thus, father and farther, though different in meaning, are still similar in phonic structure in that both are homophones according to their (RP) received pronunciation /fa: $\delta ə /$.

\section{Lexical-doublet repetition}

This type refers to the recurrence of lexical doublets across the text that would achieve a cohesive function. A doublet is usually repeated twice and occasionally three times setting a pattern of lexical-doublet chain that interconnects various parts of the text. Given that it is a unit of two constitutive elements, the doublet could be seen as creating more than one tie, by dint of its elements, or what might be called a compound cohesive tie. Put another way, the cohesive relation between two (or more) occurrences of a doublet may be described as twofold, i.e., involving two ties. This is illustrated as follows:

FIGURE 1

A Compound Cohesive Tie

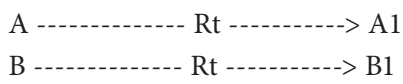

where A stands for the first member of the lexical doublet and B for the second member; similarly, A1 and B1 symbolise the repetition of the two members while Rt is a repetition tie. A number of examples are discussed below to see how such repetitive patterns are rendered in the TT. 


\subsection{Translation strategies}

Generally, translation strategies tackle either the first or second occurrence of a lexical doublet, which results in a shift of patterns in the TT. A set of strategies are described here.

\subsubsection{Literal translation}

The fifth example below demonstrates how this strategy operates on lexical-doublet repetition.

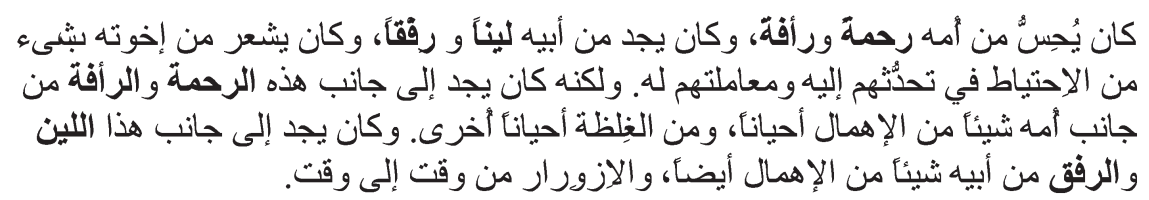

(Hussein Pt. 1: 17)

He experienced much tenderness and consideration from his mother, and from his father lenience and kindness, and his brothers he felt were somewhat reserved in their conversation and dealings with him. But he found side by side with this tenderness and consideration on the part of his mother a certain amount of negligence sometimes, and at others even harshness. And side by side with the lenience of his father he found a certain amount of negligence also, and even severity from time to time.

(Hussein 1932/1997: 15, translated by Paxton)

It is clear that the ST texture is carefully planned as it is characterised by repetitive patterns of various kinds. At large, there is syntactic parallelism between the clauses and sentences of the text that take the form of highly symmetrical patterns. Included are two sets of lexical doublets that are reiterated in the ST: الرحمة و الر أفة and اللين و الرفق (besides their indefinite forms). The translation strategy is to preserve the cohesive ties in the TT by rendering the lexical doublets literally, at least with the first doublet. Thus, الرحمة و الر أفة is replaced by tenderness and consideration in both occurrences, whereas اللين و الرفقو is rendered as lenience and kindness in the first instance and lenience in the second. With this latter case, a strategy of compression is activated where the translation choice is condensed.

\subsubsection{Translation by synonymy}

This strategy covers either or both terms of the lexical doublet. One item that is rendered synonymous is given in the sixth example below.

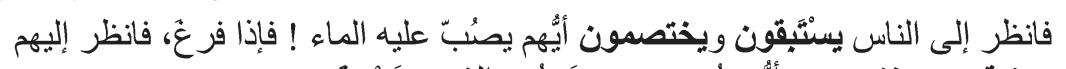

(Hussein Pt. 1: 90)

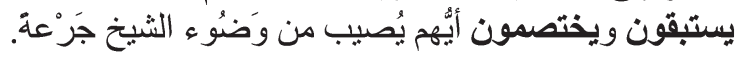

Then see how the people vie with one another and quarrel as to who shall pour the water on him! And when that is done see how they race and quarrel to get a drink of the water of his ablutions!

(Hussein 1932/1997: 53-54, translated by Paxton)

Here, lexical cohesion is sustained in the ST by repetition of ويختصدون يسنتَفقون. The translation strategy has changed the repetition tie between the two occurrences of يسنتيقتقن into a synonymy tie, i.e., vie and race. 


\subsubsection{Translation by metaphor}

This strategy incorporates a metaphorical element in the translating of a lexicaldoublet chain, such as in the seventh example below.

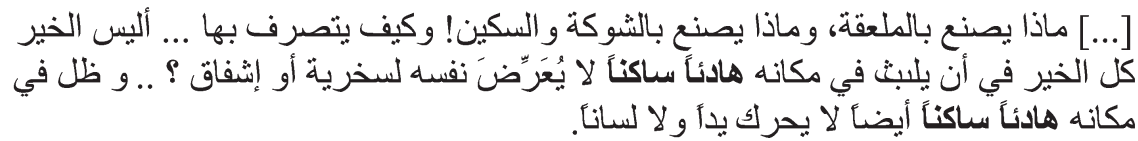

(Hussein Pt. 3: 68)

What should I [he] do with the spoon, the fork, the knife? How ought I [he] to handle them? Would it not be altogether better just to sit where I [he] was without lifting a finger or saying a word, so not exposing myself [himself] either to ridicule or sympathy? So I [he] remained that way, still and quiet, without moving hands or lips. (Hussein 1976/1997: 310-311, translated by Cragg)

The first instance of the adjectival doublet هادئ ساكنا is rendered metaphoric as without lifting a finger or saying a word whilst the second occurrence has the lexical equivalent still and quiet. This shift in the kind of cohesive relation from lexical repetition to metaphorical is reinforced by another relation in the TT, namely meronymy between the metaphorical phrase and the utterance without moving hands or lips. In other words, finger is part of hand while word relates to lips or specifically to moving lips which denotes speech.

\subsubsection{Translation by an elliptical element}

This strategy, shown in the eighth example below, utilises the device of ellipsis to create cohesion in the TT. The second occurrence of a lexical doublet becomes elliptical, shifting the ST repetition pattern into an elliptical one.

(Hussein Pt. 3: 106)

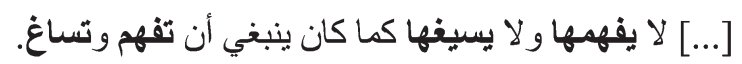

I [he] was not absorbing and grasping them as I [he] should $\{\underline{\varnothing}\}$.

(Hussein 1976/1997: 348, translated by Cragg)

There is a repetition tie between the active verb doublet لا يفهيها ولا يسيغها and passive verb doublet تفهم و تساغ. The translator has deleted the second instance by opting for an elliptical element and thus reducing the level of redundancy. In the subordinate clause, it is the main verb that is elliptical $\{\varnothing\}$, not the auxiliary.

\section{Phrase repetition}

Lexical cohesion is also sustainable by repeating the same phrase across a stretch of text. This takes the form of explicit recurrence of a phrase, or even a clause, that has the function of connecting a number of sentences. It is also possible to find larger chunks of text being interlinked by this kind of repetition. Generally, the translators have employed a strategy whereby the ST cohesion by phrase repetition is shifted into a pattern of cohesion based on variation. 


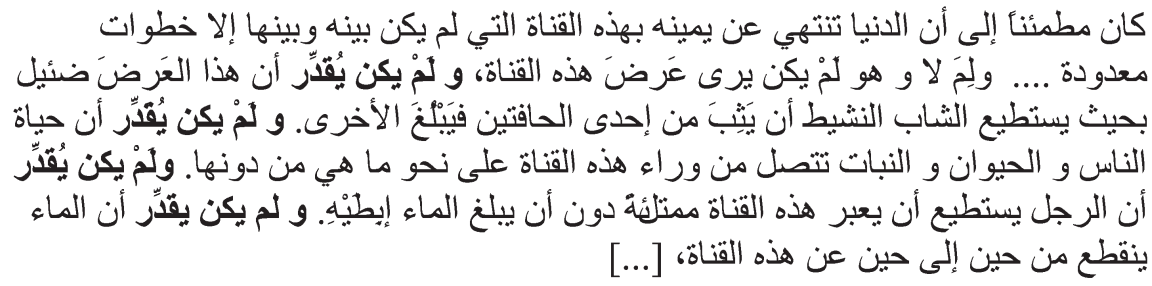

(Hussein Pt. 1: 12)

$$
\text { لم يكن يقدّر هذا كتَّه [...] }
$$

He was convinced that the world ended to the right of him with the canal, which was only a few paces away from where he stood ... and why not? For he could not appreciate the width of this canal, nor could he reckon that this expanse was so narrow that any active youth could jump from one bank to the other. Nor could he imagine that there was human, animal and vegetable life on the other side of the canal just as much as there was on his side; nor could he calculate that a grown man could wade across this canal in flood without the water reaching up to his armpits; nor did he conjecture that from time to time there was no water in it [...] None of these things did he ponder [...]

(Hussein 1932/1997: 12-13, translated by Paxton)

In this ninth example, the ST includes the anaphoric repetition of the phrase at the beginning of successive sentences. This instance of repetition is not only intended to serve a cross-referencing function between a series of sentences, but also to build up textual cohesion at inter-paragraph level. Moreover, the tendency for creating cohesion by phrase repetition in the ST is countered by a predilection for variation in terms of synonymy in the TT. Therefore, the phrase is replaced by synonyms or near-synonyms all the way through: nor could he reckon, Nor could he imagine, nor could he calculate, nor did he conjecture, and None of these things did he ponder. It is conspicuous that the pressure of the context for realising appropriate collocative relationships has constituted another factor in determining the lexical choices in the TT. To take one example, the translation item reckon means to calculate or determine by reference to a fixed point or basis, i.e., it has to do with dimensions. This sense is retrieved from the very context of the text as in the underlined

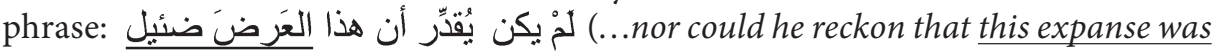
so narrow). The excerpt is the opening paragraph of the second chapter of Tāhā Hussein's autobiography (Part 1). By introducing the repetition, the author may have had the intention of harking back to the repetition of the item يذكر in the first chapter, as if he wanted to emphasise that he remembers but could not reckon things properly (see the first example). It may be argued here that these two instances of repetition (opening Chapters 1 and 2) are associated by collocation and thus serve an inter-chapter cohesive function.

\section{Rhetorical repetition}

The rhetorical function of repetition is concerned with the meaning that formal repetition invokes in the mind of the reader. By the recurrence of certain lexical items in a short piece of text, a foregrounded image is projected on the surface of the text 
signalling a semantic weight that goes beyond the mere senses of the repeated utterances. Thus, rhetorical repetition can be considered an extra structure, extra layer, or extra regularity aimed at triggering extra meanings as well as organizing the overall composition of discourse. Although rhetorical repetition in literature has been extensively studied, little attention has been paid to this phenomenon in literary translation studies (Hatim and Mason 1997; Abdulla 2001). In general, translation theorists consider repetition as a motivated feature that should be retained in the TT:

[Re]iteration of text items is always motivated. This form of passive intertextuality has to be considered by the translator in terms of its overall function within the text. Opting for a synonym or a paraphrase when what is required is verbatim reiteration can mar the communicative effect intended (Hatim and Mason 1990: 124).

As regards instances of rhetorical repetition in this study, it is found that repetition has been approached by a number of translation strategies ranging between literal translation, variation, and reduction. This is manifested in tendencies by the translators to favour one technique over another. For instance, Wayment seems to completely ignore repetition opting instead for variation and thus compromising the rhetorical function of the ST. Only the complete transfer of the repetition into the TT could relay the rhetorical message of the ST. Other translators, in general, have shown a preference for keeping the repetition device in the TT.

In the following examples, heed will be paid to rhetorical repetition as a foregrounding device and its ramifications for literary translation. More specifically, the focus will be on the relationship of a single rhetorical form in the ST to its meaning and how that meaning is mediated through the process of translation.

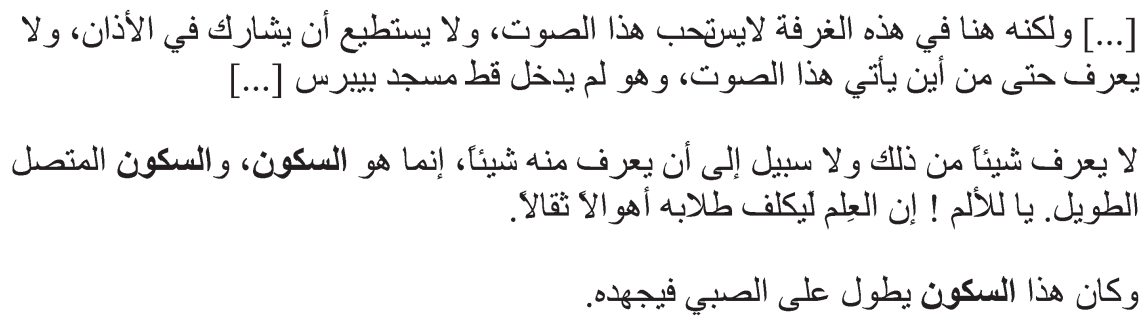

(Hussein Pt. 2: 36-37)

But here in this room the boy loathed hearing the call to prayer, for he could not join in it and did not even know where it came from. He had never once been in the Mosque of Baibars [...]

Of all this he knew nothing, and there was no way of learning it, only this waiting, this eternal immobility. Ah, what agonies one can be condemned to by a passion for learning!

This interminable blankness was nothing if not exhausting.

(Hussein 1943/1997: 128-129, translated by Wayment)

There are two instances of repetition in the extract: the first is the repetition of the word السكون and the second is the repetition of the phrase (or some variety of it) لا يعرف شيئً . As far as the first recurrence is concerned, the translator opts for variation, i.e., waiting, immobility, and blankness, replacing the ST general term with near synonyms. This is quite oblivious to the fact that the author intends the notion 
of nothingness (or blankness) which is potently relayed by this repetition and the context wherein it occurs. The key word for the theme of nothingness is repeated three times. Another set of terms that reinforces the rhetorical meaning in the passage is: لا سبيل إلى أن يعرف - لا يعرف شيئً - لا يعرف. In the TT, the following items refer to the same notion: did not even know - knew nothing - no way of learning, while the word nothing is repeated twice. In short, the meaning is lexicalised in both the ST and TT.

In the eleventh excerpt below, rhetorical repetition serves a complex and multifaceted purpose that would relate a variety of things into one unity.

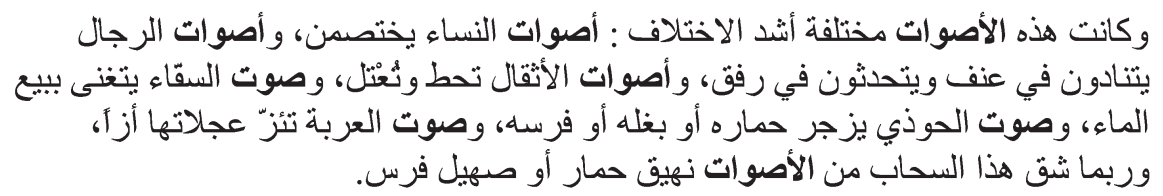

(Hussein Pt. 2: 4)

There was in fact a remarkable variety of sounds. Voices of women raised in dispute, $\{\underline{\emptyset}\}$ of men shouting in anger or peaceably talking together; the noise of loads being set down or picked up; the song of the water-carrier crying his wares; the curse of a carter to his horse or mule or donkey; the grating sound of cart-wheels; and from time to time this confused whirl of sounds was torn by the braying of a donkey or the whinnying of a horse.

(Hussein 1943/1997: 106, translated by Wayment)

The passage is a picture of a street scene where the foregrounded paradigm is the vocabulary for أصوات, i.e., sounds in its neutral sense. The item أصو ات and its singular form صوت are repeated no fewer than eight times in this short utterance. Apparently, the author uses the term to interrelate an assortment of things into a text world wherein various agents or objects participate: النساء (women), الرجال (men), الأنقال (loads), السقاء (the water-carrier), الحوذي (a carter), العربة (the cart), حمار (a har (a) donkey), and فرس (a horse). The translator has simply split the ST paradigm into two: one representing a repetitive lexical set as in sounds, sound, and sounds and another denoting the hyponymic set sound, voices, and noise, where sound is a superordinate for the other two co-hyponyms. This intervention has resulted in watering down the ST rhetorical aspect and the author's point of view.

Wayment's bias for variation is evident in the above translation. However, it may be argued that such variations in terms of near synonyms or other sub-categories are not merely substitutes in their own right, but are rather intended to mime explicitly the way the ST pattern functions. The pattern is set in a way so as to draw attention now to this and then to that aspect of meaning and so build up a multi-sided picture of the whole situation. Thus, the sounds are seen at one point in relation to human beings (voices, song, curse), at another in relation to inanimate objects (noise, [the grating] sound), and still at another in relation to animals (sounds [torn by the braying ... and whinnying]). These perspectives are rather complementary and, by specificity, the relation between them is shifted into an explicit one in the TT. In the ST, though, the notion of multi-sidedness is expressed by formal repetition and thus remains implicit as to evaluation, which underlies the author's aversion for explicit meaning and his interest (as a sightless person) in sounds in general. 
The notion of multi-sidedness is also expressed in the twelfth example where different concepts are interlinked by repetition.

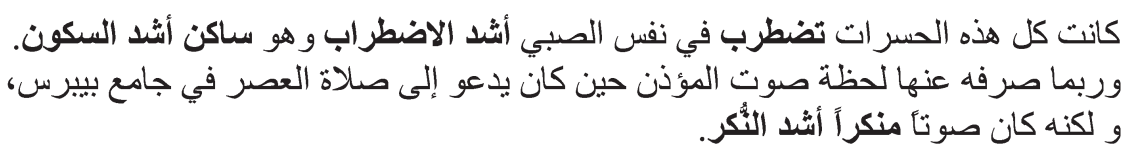

(Hussein Pt. 2: 36)

All these memories kept crowding in on the boy's brain as he lay there in utter immobility. His dreams were cut short for a moment by the call of the muezzin to afternoon prayer from the Mosque of Baibars. The man's voice was utterly hateful to the boy.

(Hussein 1943/1997: 128-129, translated by Wayment)

The repetition of أشند incorporates root repetition of other lexemes as highlighted above. Having the highest degree of intensification and flanked by root recurrence, the item is seen as cohesive throughout the passage. In the TT, the word is replaced by zero occurrence, utter, and utterly. In the case of zero occurrence, the translator condenses the semantic load of the ST phrase into a compressed one as in crowding in. In the first two clauses, the phrases تضطرب ... أشد الاضطر اب and are linked by two devices: lexical-item repetition and antonymy. The translation strategy, however, is to tone down the level of cohesion by untying the repetition while preserving the antonymous tie. This translation solution misses one important function of the reiteration across the passage, that is, the linking up of diverse concepts or meanings that would seem otherwise unrelated. The repeated

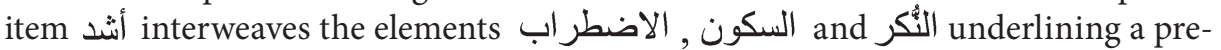
occupation on the part of the writer with the whole situation. By conferring on the senses of the three lexemes, the repetition projects an implicit image wherein the writer hates not only the man's voice but also the crowding in and immobility. This is hardly captured in the TT. The patterning of root-echoing extended along a stretch of text may be considered an effective device in linking up various parts into a whole unit. Apart from its adverbial function, the cognate accusative structure can be exploited in text-building by creating a cohesive chain.

In the thirteenth and fourteenth examples, a strategy of pervasive variation leads to obliterating the recurrence and detracting from equivalence of text focus.

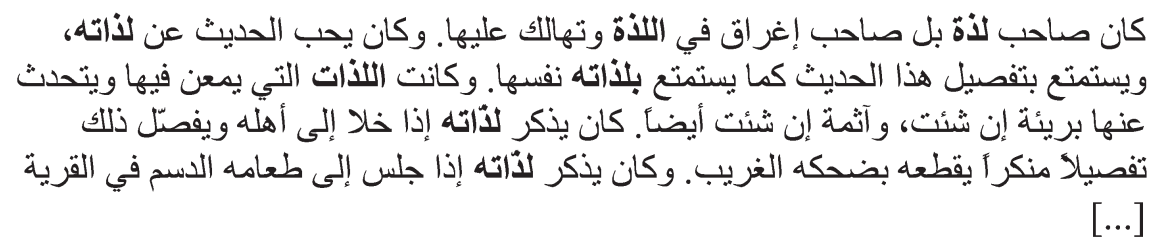

(Hussein Pt. 2: 57)

He was a sensualist, a man passionately addicted to pleasure. He loved talking about his orgies and derived as much if not more enjoyment from a detailed description of them than he did from the experiences themselves. The pleasures he thought and talked about so much might be considered vicious or venial according to the way you looked at them. He used to describe his intimate relations with his wife, with a wealth of unpleasant details, which he punctured from time to time with that incredible laugh. Or he would recall the delights of the rich greasy food he ate in the country [...] (Hussein 1943/1997: 142, translated by Wayment) 
In the ST, the term لذة (pleasure) (and its plural form لذّات recurs seven times. The complexity of the repetition foregrounds the device, which signals to the reader/ translator to be alert for implied significance. Pleasure assumes great prominence in the life of the character and this is why the repetitive device carries a marked rhetorical weight. The translator opts for variation with the result that the element of pleasure becomes insignificant and the rhetorical momentum of the ST being damaged. What happens is that the neutral, general term لذة is rendered by a set of replacements in the TT that turn the ST implicit associations into explicit ones: sensualist, pleasure, orgies, experiences, pleasures, intimate relations, and delights. Whilst sensualist is lowest on the scale of generality, experiences assumes a highest point. One may also speculate that the author's stylistic choices could be justified on the grounds of his reluctance to use explicitly pejorative or offensive expressions. That is, for a man of letters like him assuming a prestigious status in a conservative society, it must be inappropriate to articulate meticulous details concerning intimate relations among people. This line of reasoning is well supported by the observation that the author does not take up sensitive subjects in any explicit detail in his autobiography. In terms of the norms of the ST culture, the writer never violates the rules of politeness and decency in his community and therein the ST is seen to appeal to the expectations of the ST native readers at a certain period of time.

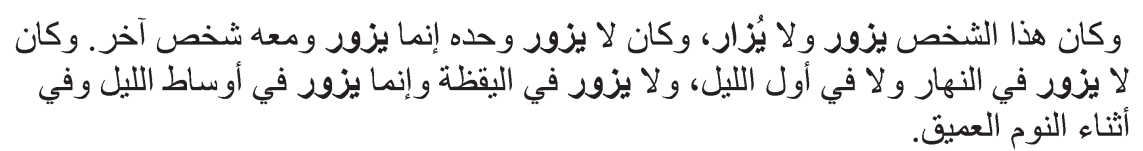

(Hussein Pt. 2: 94)

This individual paid visits but never received any. He never came alone, but always $\{\underline{\varnothing}\}$ with some other visitor. He never appeared in the daytime or in the first part of the night or $\{\underline{\emptyset}\}$ in the early morning. He came only in the dead of night, at the time of the deepest sleep.

(Hussein 1943/1997: 167, translated by Wayment)

In this example, the theme of visiting is highlighted by the heavy use of repetition. The active verb يزيز يز ار to visit (and passive form, is repeated seven times, apparently underlying the author's intention to emphasise his ironic stance towards a specific situation. The translation strategy, however, has been to dismantle the repetition chain and establish cross-reference by variation and ellipsis, as illustrated in the above translation. This led to demolishing the rhetorical building block of the ST and depriving the TT readership from access to both the message and content of the ST. A possible rendering that will maintain the form and meaning of the ST should be something like the following:

This individual paid visits but never received any visitor. He never visited alone, but always visited accompanied by some other visitor. He never visited in the daytime or in the first part of the night; he never visited in the early morning, but visited only in the dead of night, at the time of the deepest sleep.

By using the base form of the verb visit along with the derived form visitor, such a translation is likely to convey the rhetorical meaning implied by the ST.

Another translator has employed a strategy of reduction whereby repetition is diluted at some cohesive links, as shown in the fifteenth example. 


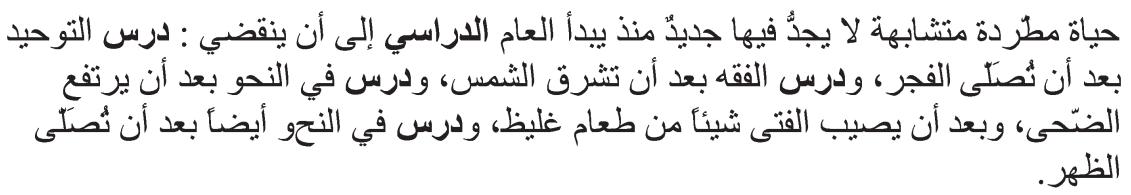

(Hussein Pt. 3: 3)

It was a life of unrelieved repetition, with never a new thing, from the time the study year began until it was over. After the dawn prayer came the study of Tauhid, the doctrine of the divine unity; then $\{\underline{\emptyset}\} \underline{\text { fiqh }}$, or jurisprudence, after sunrise; then the

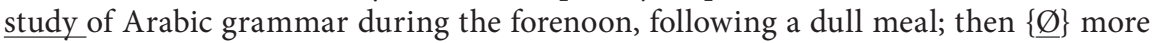
grammar in the wake of the noon prayer.

(Hussein 1976/1997: 245, translated by Cragg)

The ST involves the recurrence of the item درس four times in a relatively short stretch. Rhetorically, the device foregrounds the notion of monotony or repetitiousness. Indeed, the idea is overtly lexicalised in the ST to the extent that it becomes the theme of the passage: حياة مطردة منشابهة لا يجدُ فيها جديدُ (It was a life of unrelieved repetition, with never a new thing). It may be claimed that the monotonous tempo of repetition sounds repugnant even to the hypersensitive ear of the ST author. In the TT, however, the translator introduces the word repetition, but falls short of preserving the association between the rhetorical function of the device and the whole notion of the passage by opting for ellipsis.

In short, the omission of repetition in the above examples is likely to have compromised the rhetorical function of the text and rendered it rather loose. Generally, the translation of the first and third parts of the autobiography has shown highly sensitive approaches in dealing with rhetorical repetition. This has culminated in a strategy characterised by meticulous observance of the ST repetitive patterns and thus retaining the rhetorical function of repetition intact. The strategy also entails accessibility and recoverability of both the meaning and content of the ST. This is displayed in the sixteenth example where repetition is utilized as an effective means to express strong feelings or emotions in an emotive context that strikes the reader/listener.

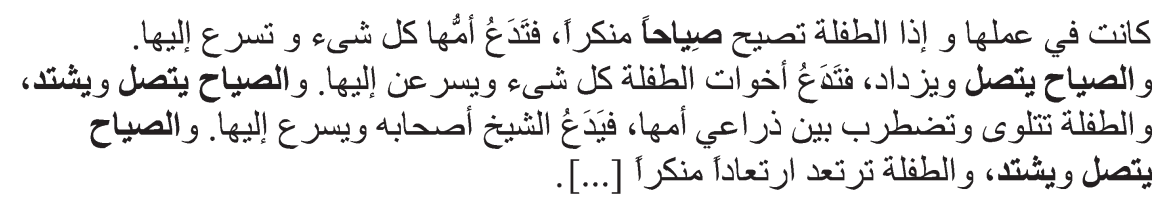

(Hussein Pt. 1: 121)

She was going about her work, when the little girl began to utter horrible cries. Her mother at once left everything and hastened to her. The cries continued and increased, so that the child's sisters also left everything and hastened to her. The crying continued louder than ever, and the child twisted and turned in her mother's arms. The sheikh, too, left his friends and hastened to her. The cries continued louder than ever, and the little girl quivered horribly [...].

(Hussein 1932/1997: 71-72, translated by Paxton)

The excerpt describes a situation whereby gradual build-up of strong emotions goes hand in hand with cumulative patterns of repetition. In actual fact, the emotive meaning is heightened by a variety of repetitive, lexical sets. These may be compared with their TT equivalents as follows: 
TABLE 1

Number of occurrences (N) in ST and in TT

\begin{tabular}{|c|c|c|c|}
\hline ST & $\mathrm{N}$ & TT & $\mathrm{N}$ \\
\hline صِياح & 4 & $\begin{array}{l}\text { cries } \\
\text { crying }\end{array}$ & $\begin{array}{l}3 \\
1\end{array}$ \\
\hline يتصل & 3 & continued & 3 \\
\hline يشتد & 2 & louder than ever & 2 \\
\hline يَدَعُعُ & 3 & left & 3 \\
\hline يسرع & 3 & hastened & 3 \\
\hline منكراً & 2 & $\begin{array}{l}\text { horrible } \\
\text { horribly }\end{array}$ & $\begin{array}{l}1 \\
1 \\
\end{array}$ \\
\hline كل شيء & 2 & everything & 2 \\
\hline
\end{tabular}

As the table shows, the translator has adopted a strategy of literal translation through selecting corresponding equivalents and preserving the same frequency of occurrences of the items repeated. Given this, the translation has most likely managed to reproduce the parallel effect of maintaining the dynamic aspect of the ST by observing its unexpectedness.

\section{Conclusion}

It has been argued that the style of the text under consideration has as its main feature the utilization of repetitive patterns for textual and rhetorical ends. The marked role of repetition is to foreground a mental image or invoke emotions in emotive language. Notions of multisidedness, nothingness, and irony are only some. Meaning externalised by foregrounding is almost neutralized in translation by backgrounding, hence replacing rhetorical repetition with pervasive variation. This may be the case with the translation of the autobiography's second part. Apparently, Wayment (the translator of the second part) was conscious of acting contrary to the textual norms of the ST and in preference for the TL norms, otherwise she would not have felt the need to justify her translation in a preface:

Taha Hussein's style has become a byword for charm and grace, and it is indeed rash to attempt to render its qualities in English. I have tried to avoid literal translation, which only results in a sort of spurious local colour such as hinders genuine comprehension. The graceful assonances and repetitions of the original have also disappeared, though I can only hope that some of its charm remains (Wayment, Preface. In: Hussein 1943/1992: 102-103; italics are mine).

By avoiding literal translation, the translator makes her initial decision, in the light of the initial norm (Toury 1995), as to how the translation should look. And by ignoring repetition, she produces a target text that falls short of relaying one important stylistic aspect of the original text. Indeed, the translation of the second part of the autobiography is characterised mainly by the absence of lexical repetition, contrary to the translations of the first and third parts. Thus, we end up with a translated autobiography that misrepresents the original author as passing through three stages of linguistic, stylistic development whereby he uses repetition in the first stage, averts it in the second, and re-uses it in the third. This gives rise to the question of how to come to translate a text that consists of several parts by several translators. 
On the whole, the translational norms seem to lean more towards the acceptability pole than the adequacy pole. The strategies for translating lexical repetition highlighted the translators' individual attitudes towards the ST's norms and their adherence to the linguistic and cultural norms prevalent in the TL environment.

\section{NOTES}

1. Hussein, Tāhā (n.d.): al-Ayyam. Pts. 1-3. Cairo: Daar al-ma’aarif.

2. Hussein, Tāhā (1932/1997): An Egyptian Childhood. (Translated by E. H. Paxton). The Days, pt. 1. Cairo: The American University in Cairo Press, 1-93.

3. Hussein, Tāhā (1943/1997): The Stream of Days. (Translated by Hilary Wayment). The Days, pt 2. Cairo: The American University in Cairo Press, 97-233.

4. Hussein, Tāhā (1976/1997):): A Passage to France. (Translated byKenneth CrAGG). The Days, pt. 3. Cairo: The American University in Cairo Press, 235-406.

\section{REFERENCES}

Abdulla, Adnan K. (2001): Rhetorical Repetition in Literary Translation. Babel. 47(4):289303.

BAKer, Mona (1992): In Other Words: A Coursebook on Translation. London: Routledge.

BARTSCH, Renate (1987): Norms of Language. London: Longman.

Chesterman, Andrew (1997): Memes of Translation: the Spread of Ideas in Translation Theory. Amsterdam: John Benjamins.

De Beaugrande, Robert and Dressler, Wolfgang (1981): Introduction to Text Linguistics. London: Longman.

Dickins, James, Hervey, Sándor and Higgins, Ian (2002): Thinking Arabic Translation: A Course in Translation Method: Arabic to English. London: Routledge.

Gutwinski, Waldemar (1976): Cohesion in Literary Texts: A Study of Some Grammatical And Lexical Features of English Discourse. The Hague: Mouton.

HallidaY, M.A.K. and Hasan, Ruqaiya (1976): Cohesion in English. London: Longman.

Hasan, Ruqaiya (1984): Coherence and Cohesive Harmony. In: James Flood, ed. Understanding Reading Comprehension: Cognition, Language, and the Structure of Prose. Delaware: International Reading Association, 181-219.

Hatim, Basil and Mason, Ian (1990): Discourse and the Translator. London: Longman.

Hatim, Basil and Mason, Ian (1997): The Translator As Communicator. London: Longman.

Hoey, Michael (1991): Patterns of Lexis in Text. Oxford: Oxford University Press.

Leech, Geoffrey (1969): A Linguistic Guide to English Poetry. London: Longman.

LEECH, Geoffrey and SHORT, Mick (1981): Style in Fiction. London: Longman.

Schäffner, Christina (1999): The Concept of Norms in Translation Studies. In: Christina SCHÄFfner, ed. Translation and Norms. Clevedon: Multilingual Matters, 1-8.

Toury, Gideon (1995): Descriptive Translation Studies - And Beyond. Amsterdam: John Benjamins.

Vinay, Jean-Paul and Darbelnet, Jean (1958/1995): Comparative Stylistics of French and English: A Methodology for Translation. (Translated and edited by Juan C. SAGER and M.-J. HameL). Amsterdam: John Benjamins Publishing.

Wenmeier, Sally (Ed.) (2000): Oxford Advanced Learner's Dictionary of Current English (6 ${ }^{\text {th }}$ ed.). Oxford: Oxford University Press.

Wright, Keith (1965): Rhetorical Repetition in T. S. Eliot's Early Verse. A Review of English Literature. 6(2):93-100. 